\title{
PROSTAGLANDINS F AND OVULATION IN MICE*
}

\author{
I. F. LAU, S. K. SAKSENA AND M. C. CHANG \\ Worcester Foundation for Experimental Biology, \\ Shrewsbury, Massachusetts 01545, U.S.A.
}

(Received 2nd April 1974)

Prostaglandins (PGs) are known to exert profound physiological and pharmacological effects on the female reproductive system in women and in many other species (Weeks, 1972; Labhsetwar, 1974). Indomethacin and aspirin, inhibitors of prostaglandin biosynthesis, block PMSG-induced ovulation in immature (Armstrong \& Grinwich, 1972; Orczyk \& Behrman, 1972) and adult female rats (Tsafriri, Lindner, Zor \& Lamprecht, 1972). In the rabbit, ovulation induced by HCG, LH or coitus was blocked by indomethacin (O'Grady, Caldwell, Auletta \& Speroff, 1972). In mice, ovulation was blocked with indomethacin and the effect was reversed by injecting prostaglandins $E_{2}$ or $F_{2 \alpha}$ (Saksena, Lau \& Shaikh, 1974). All these studies provide indirect evidence that PGs are involved in the process of ovulation. A more direct approach, namely the specific binding of endogenous PGs by anti-PG sera raised in rabbits, was used in the present study. Attempts were also made to reverse the antiovulatory effect of antisera to prostaglandin $\mathrm{F}$ by administration of $\mathrm{PGF}_{2 \alpha}$. Anti-PGF $2 \alpha$ serum does not cross-react with PGAs or PGEs, but there is an $80 \%$ crossreaction with $\mathrm{PGF}_{1 \alpha}$.

Mature female Charles River CD-1 mice (22 to $26 \mathrm{~g}$ ) were housed under standard laboratory conditions. Vaginal smears were taken every morning and the stage of the oestrous cycle was identified in unstained wet vaginal smear preparations as described by Allen (1922). After two consecutive oestrous cycles, pro-oestrous females were allocated to different experimental groups. The treatment schedules are shown in Table 1 . Between 09.00 and 10.00 hours on the morning of oestrus, the mice were killed by cervical dislocation, and the oviducts were excised and flushed with saline through the fimbria using a 30gauge needle attached to a syringe. Cumulus cells were removed with $0.1 \%$ hyaluronidase (bovine testis; Sigma Chemical Co.) and the number of ova were counted under a dissecting microscope using $\times 25$ magnification.

Since the numbers of ova recovered from the control animals treated either with normal rabbit serum or rabbit serum which had been dialysed against saline for $72 \mathrm{hr}$ were not different, the results for all the serum-treated animals were pooled for comparison (Table 1). It can be seen that a dose of $200 \mu \mathrm{g}$ indomethacin (Merck, Sharpe \& Dohme) injected at 19.30 hours on the day of pro-oestrus blocked ovulation in all the treated animals. A single intraperitoneal injection of $0.2 \mathrm{ml}$ anti-PGF serum at 17.30 hours on the day of pro-oestrus was followed by examination on the day of oestrus. No eggs were found in the

* Reprint requests to Dr M. G. Chang. 
oviducts of $40 \%$ of the animals. When the dose of anti-PGF serum was increased to $0.3 \mathrm{ml}$, ovulation was blocked in $88.9 \%$ of the animals, but treatment at 10.00 hours was not found to be as effective. Administration of $\mathrm{PGF}_{2 \alpha}(500 \mu \mathrm{g})$ at 16.00 and 21.00 hours and anti-PGF serum at 17.30 hours $(0.3 \mathrm{ml}$ intraperitoneally) resulted in the appearance of eggs in the oviducts of $61.5 \%$ of the treated animals.

In the present study, a single injection of indomethacin or anti-PGF serum given close to the time of the expected ovulatory LH surge inhibited ovulation in mice. When PGF $_{2 \alpha}$ was administered before and after anti-PGF serum treatment, however, the inhibitory effect of the anti-PGF serum on ovulation was reduced to $38.5 \%$. Varaundhi \& Chobdieng (1972), Carlson, Barcikowski \& McCracken (1973) and Saksena, Lau \& Chang (1974) reported that PGF ${ }_{2 \alpha}$ stimulated release of $\mathrm{LH}$ in rats, sheep, and rats and hamsters, respectively. It is possible that treatment with anti-PGF serum inhibited ovulation by altering the $\mathrm{LH}$ surge but that this was offset by the administration of $\mathrm{PGF}_{2 \alpha}$.

Table 1. Effects of indomethacin or anti-PGF serum on ovulation and their reversal by $\mathrm{PGF}_{2 \alpha}$ in mice

\begin{tabular}{|c|c|c|c|c|c|}
\hline Treatment* & Dose & $\begin{array}{c}\text { Hour of } \\
\text { treatment } \dagger\end{array}$ & $\begin{array}{c}\text { No. of mice } \\
\text { ovulating/no. treated }\end{array}$ & $\begin{array}{c}\text { No. of tubal ova } \\
(\text { Mean } \pm \text { S.E. })\end{array}$ & $\begin{array}{c}\text { Mice ovulating } \\
(\%)\end{array}$ \\
\hline Controlf & $0.3 \mathrm{ml}$ & $\begin{array}{l}17.30 \\
10.30\end{array}$ & $9 / 10$ & $7 \cdot 4 \pm 1 \cdot 1$ & $90 \cdot 0$ \\
\hline Indomethacin & $200 \mu \mathrm{g}$ & 19.30 & $0 / 6$ & - & 0.0 \\
\hline $\begin{array}{l}\text { Anti-PGF } \\
\text { serum } \\
(1: 800)\end{array}$ & $\begin{array}{l}0.2 \mathrm{ml} \\
0.3 \mathrm{ml} \\
0.3 \mathrm{ml}\end{array}$ & $\begin{array}{l}17.30 \\
17.30 \\
10.00\end{array}$ & $\begin{array}{l}3 / 5 \\
2 / 18 \\
5 / 8\end{array}$ & $\begin{array}{l}6 \cdot 7 \pm 1 \cdot 8 \\
5 \cdot 5 \pm 2 \cdot 5 \\
7 \cdot 0 \pm 1 \cdot 3\end{array}$ & $\begin{array}{l}60 \cdot 0 \\
11 \cdot 1 \\
62 \cdot 5\end{array}$ \\
\hline $\begin{array}{l}\text { Anti-PGF } \\
\text { serum } \\
+ \text { PGF }_{2 \alpha}\end{array}$ & $\begin{array}{l}0.3 \mathrm{ml} \\
500 \mu \mathrm{g} \\
500 \mu \mathrm{g}\end{array}$ & $\begin{array}{l}17.30 \\
16.00 \\
21.00\end{array}$ & $8 / 13$ & $5 \cdot 6 \pm 1 \cdot 1$ & $61 \cdot 5$ \\
\hline
\end{tabular}

* Antiserum to PGF was injected intraperitoneally; other substances were given subcutaneously. $\dagger$ Treatments were conducted on the day of pro-oestrus and ova were recovered on the day of oestrus between 09.00 and 10.00 hours.

$\ddagger$ Treated with rabbit serum (see text).

Our results agree with the observation that ovulation was blocked in rabbits after intrafollicular injection of antiserum to $P G_{2 \alpha}$ and indomethacin (Armstrong, Grinwich, Moon \& Zamecnik, 1974) and support the possibiliy that PGs are involved in ovulation. Since indomethacin has a wide range of inhibitory effects (Sorrentino, Capasso \& DiRosa, 1972), the choice of a specific PGF-binding agent (anti-PGF serum) used in the present study provides better evidence that PGFs are involved in ovulation. The fact that indomethacin treatments were more effective when given at 19.30 hours (Saksena, Lau \& Shaikh, 1974) could be due to the short half-life of this drug compared to that of the anti-PGF serum whose effect may have persisted until the time of the LH surge.

Since the presence of eggs in oviducts was the criterion for ovulation in this study, it is possible that treatment with anti-PGF serum was followed by failure of the eggs to enter the oviducts as a result of absence of the stimulatory effects of PGFs. Since ovulation results from a sequence of interdependent 
events, another possibility could be failure of the release of gonadotrophins. It appears that PGFs are involved in the induction of ovulation in mice.

Grateful thanks are due to Dr W. Stylos for providing anti-PGF serum. This study was supported in part by grants from NICHD (HD 03472) and the Ford Foundation.

\section{REFERENGES}

AlleN, E. (1922) The oestrous cycle in the mouse. Am. F. Anat. 30, 297.

Armstrong, D. T. \& GRINwich, D. L. (1972) Blockade of spontaneous and LH induced ovulation in rats by indomethacin, an inhibitor of prostaglandin synthesis. Prostaglandins, 1, 21.

Armstrong, D. T., Grinwich, D. L., Moon, Y. S. \& ZAMECNIK, J. (1974) Inhibition of ovulation in rabbits by intrafollicular injection of indomethacin and prostaglandin-F antiserum. Life Sciences, $14,129$.

Garlson, J. G., Barcikowski, B. \& McGracken, J. A. (1973) Prostaglandin F $F_{2 a}$ and the release of LH in sheep. F. Reprod. Fert. 34, 357.

Labhsetwar, A. P. (1974) Prostaglandins and the reproductive cycle. Fedn Proc. Fedn Am. Socs exp. Biol. 33, 61 .

O'Grady, J. P., Galdwell, B. V., Auletta, F. J. \& Speroff, L. (1972) The effects of an inhibitor of prostaglandin synthesis (indomethacin) on ovulation, pregnancy and pseudopregnancy in the rabbit. Prostaglandins, 1, 97.

ORCzyK, G. P. \& BEHRMAN, H. R. (1972) Ovulation blockade by aspirin or indomethacin in vivo. Evidence for a role of prostaglandin in gonadotrophin secretion. Prostaglandins, 1, 3.

Saksena, S. K., LaU, I. F. \& Ghang, M. C. (1974) Prostaglandin $F_{2 \alpha}$ implants induced abortion: effect of progestin and luteinizing hormone concentration and its reversal by progesterone in rabbits, rats and hamsters. Fert. Steril. (in press).

Saksena, S. K., Lau, I. F. \& Shaikh, A. A. (1974) Cyclic changes in the uterine tissue content of Fprostaglandins and the role of prostaglandins in ovulation in mice. Fert. Steril. 25, 636.

Sorrentino, L., Capasso, F. \& DiRosa, M. (1972) Indomethacin and prostaglandins. Eur. F. Pharmac. 17,306 .

Tsafriri, A., Lindner, H. R., Zor, U. \& Lamprecht, S. A. (1972) Physiological role of prostaglandins in the induction of ovulation. Prostaglandins, 2, 1.

VARAUNDHI, P. \& GHoBdieng, P. (1972) Biological evidence for the direct stimulating effect of PGF $2 a$ on the release of pituitary luteolytic agent(s) of pseudopregnant rats. Prostaglandins, 2, 199.

Weeks, J. R. (1972) Prostaglandins. A. Rev. Pharmac. 12, 317. 